\title{
BELSŐPONTOS ALGORITMUS LINEÁRIS OPTIMALIZÁLÁSRA A CENTRALIZÁLÁSI EGYENLET ÁTALAKÍTÁSÁVAL
}

\section{INTERIOR-POINT ALGORITHM FOR LINEAR OPTIMIZATION BASED ON THE TRANSFORMATION OF THE CENTERING EQUATION}

\author{
Darvay Zsolt ${ }^{1}$, Takács Petra-Renáta ${ }^{1}$

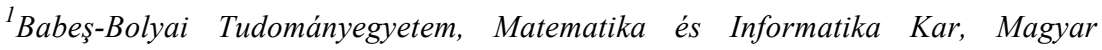 \\ Matematika és Informatika Intézet, Cím: 400084, Románia, Kolozsvár, \\ Kogălniceanu 1; Telefon: +40 264 405327, levelezési cim: darvay@cs.ubbcluj.ro
}

\begin{abstract}
In this paper we introduce a new interior-point method which is suitable for solving linear optimization problems. We apply a new type of algebraic transformation on the nonlinear equation of the system which defines the central path, namely the centering equation. Using Newton's method we obtain the search directions. We define the algorithm from the point of view of the implementation and we analyse its efficiency through an application.
\end{abstract}

Keywords: linear optimization, interior-point algorithm, search direction, Newton's method, polynomiality.

\section{Összefoglalás}

Egy új belsőpontos módszert vezetünk be, amely lineáris optimalizálási feladatok megoldására alkalmas. A centrális utat jellemző rendszer nemlineáris egyenletére, az úgynevezett centralizálási egyenletre egy új típusú algebrai átalakítást alkalmazunk. Ezt követően a Newton-módszert felhasználva kapjuk meg a keresési irányokat. Az algoritmust az implementáció szemszögéből nézve határozzuk meg, és egy alkalmazáson keresztül vizsgáljuk ennek hatékonyságát.

Kulcsszavak: lineáris optimalizálás, belsőpontos algoritmus, keresési irány, Newton-módszer, polinomialitás.

\section{Bevezetés}

A müszaki és gazdasági problémák gyakran vezetnek különböző lineáris, illetve nemlineáris optimalizálási feladatokhoz. A lineáris optimalizálásra vonatkozó hagyományos megoldási módszer a szimplex módszer, amelyet Dantzig [1] vezetett be 1947-ben. Klee és Minty [4] 1972-ben igazolta, hogy a szimplex módszer a dimenzió függvényében exponenciálisan sok lépést tehet meg. Az első belsőpontos algoritmus, amely polinom időben szolgáltat megoldást a lineáris optimalizálási feladatok esetében, Karmarkar [3] nevéhez füződik. A primál-duál belsőpontos algoritmusok általában a centrális utat követik, amely a Sonnevend [6] által bevezetett analitikus centrum fogalmához kapcsolódik. A lineáris optimalizálásra vonatkozó belső- 
pontos algoritmusok elméletéröl a Roos, Terlaky és Vial [5], Wright [7] és Ye [8] könyvekben találunk további információkat.

A belsőpontos algoritmusok sokszínüsége a különböző keresési irányok megválasztásában rejlik. Ebben a cikkben egy új lineáris optimalizálásra vonatkozó belsőpontos módszert vezetünk be. A centralizálási egyenletre egy új algebrai átalakítást alkalmazunk, majd a Newtonmódszer segítségével határozzuk meg a keresési irányokat. Ezt követően az új algoritmusra különböző numerikus eredményeket mutatunk be.

\section{A lineáris optimalizálási feladat}

Tekintsük az alábbi primál feladatot:

$$
\begin{gathered}
\min c^{T} x, \\
A x=b, \\
x \geq 0 .
\end{gathered}
$$

A feladat duálisa a következőképpen néz ki:

$$
\begin{gathered}
\max b^{T} y, \\
A^{T} y+s=c, \\
s \geq 0,
\end{gathered}
$$

ahol $A \in \mathfrak{R}^{m \times n}, \operatorname{rang}(A)=m, b \in \mathfrak{R}^{m}$ és $c \in \mathfrak{R}^{n}$. Feltételezzük, hogy a belső pont feltétel fennáll mindkét feladat esetén, tehát létezik $\left(x^{0}, y^{0}, s^{0}\right)$ úgy, hogy

$$
\begin{aligned}
A x^{0} & =b, \quad x^{0}>0, \\
A^{T} y^{0}+s^{0} & =c, \quad s^{0}>0 .
\end{aligned}
$$

A centrális út a következő rendszerrel jellemezhető:

$$
\begin{array}{r}
A x=b, \quad x \geq 0, \\
A^{T} y+s=c, \quad s \geq 0, \\
x s=\mu e,
\end{array}
$$

ahol $\mu>0$ és $x s$ a komponensenkénti szorzata az $x$ és $s$ vektoroknak, tehát $x s=\left[x_{1} s_{1}, x_{2} s_{2}, \ldots, x_{n} s_{n}\right]^{T}$. Továbbá, e az alábbi $n$-dimenziós vektor: $e=[1, \cdots, 1]^{T}$. Feltételezve, hogy $s_{i} \neq 0$, bármely $1 \leq i \leq n$ indexre, az $x$ és $s$ vektorokra az $\frac{x}{s}=\left[\frac{x_{1}}{s_{1}}, \frac{x_{2}}{s_{2}}, \cdots, \frac{x_{n}}{s_{n}}\right]^{T}$ jelölést is alkalmazzuk. Ha a belső pont feltétel fennáll, akkor egy rögzített $\mu>0$ esetén a (1) rendszernek egyértelmü megoldása van, melyet $\mu$ centrumnak nevezünk (Sonnevend [6]). Ha $\mu \rightarrow 0$, akkor a centrális út a feladat optimális megoldásához konvergál.

\section{3. Új keresési irányok}

Az elmozdulásvektorok meghatározására a [2] cikkben bevezetett módszert használjuk. Ehhez tekintsük az $\mathfrak{R}^{+}=\{x \in \mathfrak{R} \mid x \geq 0\} \quad$ felett értelmezett $\varphi: \mathfrak{R}^{+} \rightarrow \mathfrak{R}^{+}$folytonosan differenciálható és invertálható függvényt. Tetszőleges $x$ vektorra a $\varphi(x)=\left[\varphi\left(x_{1}\right), \varphi\left(x_{2}\right), \ldots, \varphi\left(x_{n}\right)\right]^{T}$ jelölést alkalmazzuk. Ekkor az (1) rendszer a következőképpen írható át:

$$
\begin{aligned}
A x & =b, \quad x \geq 0, \\
A^{T} y+s & =c, \quad s \geq 0, \\
\varphi\left(\frac{x s}{\mu}\right) & =\varphi(e) .
\end{aligned}
$$

$\mathrm{Az}$ (1) rendszer harmadik egyenletét centralizálási egyenletnek nevezzük. A (2) rendszer utolsó egyenletének módosítása egy módszert szolgáltat a keresési irányok meghatározására. A továbbiakban egy más jellegű algebrai átalakítást végzünk a centralizálási egyenleten. Legyen $v=\sqrt{\frac{x s}{\mu}}$. Ekkor az (1) rendszer harmadik egyenlete a $v^{2}=e$ alakban írható. Felhasználva azt, hogy $v>0$ a következőt kapjuk:

$v^{2}=e \Leftrightarrow v=e \Leftrightarrow v^{2}=v \Leftrightarrow v^{4}=v^{2}$.

A (2) rendszer a következőképpen írható:

$$
\begin{aligned}
A x & =b, \quad x \geq 0, \\
A^{T} y+s & =c, \quad s \geq 0,
\end{aligned}
$$




$$
\varphi\left(v^{4}\right)=\varphi\left(v^{2}\right) .
$$

A továbbiakban a $\varphi(t)=t$ esettel foglalkozunk. Ekkor a Newton-módszert alkalmazva a (4) rendszerre a következőt kapjuk:

$$
\begin{aligned}
A \Delta x & =0, \\
A^{T} \Delta y+\Delta s & =0, \\
s \Delta x+x \Delta s & =\mu \frac{v^{2}-v^{4}}{2 v^{2}-e} .
\end{aligned}
$$

Bevezetve a $d_{x}=\frac{v \Delta x}{x}$ és $d_{s}=\frac{v \Delta s}{s}$ jelöléseket a $\quad \mu v\left(d_{x}+d_{s}\right)=s \Delta x+x \Delta s$ összefüggéshez jutunk. Ezek alapján az (5) rendszer a következőképpen írható át:

$$
\begin{array}{r}
\bar{A} d_{x}=0, \\
\bar{A}^{T} \Delta y+d_{s}=0, \\
d_{x}+d_{s}=p_{v},
\end{array}
$$

ahol $p_{v}=\frac{v-v^{3}}{2 v^{2}-e}$ és $\bar{A}=\frac{1}{\mu} \operatorname{Adiag}\left(\frac{x}{v}\right)$. Tetszőleges $\xi$ vektor esetén $\operatorname{diag}(\xi)$ azt a diagonálmátrixot jelöli, melynek fóátlóján a vektor elemei találhatóak, az eredeti sorrendben.

A centrális úttól való távolság mérésére a $\delta(x, s ; \mu)=\frac{\left\|p_{v}\right\|}{2}=\frac{1}{2}\left\|\frac{v-v^{3}}{2 v^{2}-e}\right\| \quad$ jelölést használjuk, ahol \|.\| az euklideszi normát jelöli. Az algoritmus a következőképpen határozható meg.

1. algoritmus. Legyen $\varepsilon>0$ a pontossági paraméter és $0<\theta<1$ a redukciós paraméter. Továbbá, legyen $0<\rho<1$. Feltételezzük, hogy a belsö pont feltétel fennáll az $\left(x^{0}, y^{0}, s^{0}\right)$ kezdeti pontokra, $\mu^{0}=\frac{\left(x^{0}\right)^{T} s^{0}}{n}$ és $v^{0}=\sqrt{\frac{x^{0} s^{0}}{\mu^{0}}}>\frac{e}{\sqrt{2}}$.

begin $x=x^{0} ; y=y^{0} ; s=s^{0} ; \mu=\mu^{0} ;$

while $x^{T} s>\varepsilon$ do begin

$\mu=(1-\theta) \mu$;

$\mu=\min \left\{\min \left\{x_{i} s_{i}: 1 \leq i \leq n\right\}, \mu\right\}$;

meghatározzuk a $(\Delta x, \Delta y, \Delta s)-t$

$\alpha_{P}=\min \left\{-\frac{x_{i}}{\Delta x_{i}}: \Delta x_{i}<0,1 \leq i \leq n\right\}$;

$\alpha_{P}=\min \left\{\alpha_{P}, 1\right\}$;

$\alpha_{D}=\min \left\{-\frac{s_{i}}{\Delta s_{i}}: \Delta s_{i}<0,1 \leq i \leq n\right\}$;

$\alpha_{D}=\min \left\{\alpha_{D}, 1\right\}$;

$x=x+\rho \alpha_{P} \Delta x$;

$y=y+\rho \alpha_{D} \Delta y$;

$s=s+\rho \alpha_{D} \Delta s$

\section{end}

end.

Megjegyezzük, hogy a fenti algoritmusban a $\mu$ paraméter megválasztása eltér a szokásos rövid lépéses módszerektől. Ezt a módosítást az indokolja, hogy a $v>\frac{e}{\sqrt{2}}$ feltételnek teljesülnie kell a teljes algoritmus során.

\section{Numerikus eredmények}

A bevezetett algoritmus hatékonyságát egy, a $\mathrm{C}++$ programozási nyelvben írt, alkalmazással teszteltük.

1. táblázat. MPS formátumban megadott feladatok méretei

\begin{tabular}{|c|c|c|}
\hline Feladat & $\begin{array}{c}\text { Sorok } \\
\text { száma }\end{array}$ & $\begin{array}{c}\text { Oszlopok } \\
\text { száma }\end{array}$ \\
\hline afiro.mps & 27 & 32 \\
\hline sc50a.mps & 50 & 48 \\
\hline sc105.mps & 105 & 103 \\
\hline sc205.mps & 205 & 203 \\
\hline
\end{tabular}

A Netlib könyvtár szabványos MPS formátumban megadott feladataira futtattuk a programot [9]. A következő kezdeti 
értékekkel dolgoztunk: $\theta=0.1, \rho=0.95$, $\varepsilon=0.0001, \mu^{0}=1$ és $x^{0}=y^{0}=s^{0}=e$. A feladatokra vonatkozó méreteket az 1 . táblázat tartalmazza.

A 2. táblázatban az egyes feladatok belsőpontos iterációinak a számát mutatjuk be. Mindkét esetben az 1. algoritmussal dolgoztunk, az első oszlop az eredeti, a második pedig a módosított keresési iránnyal meghatározott algoritmusra vonatkozik. Az általunk javasolt módosított irányokat az (5) rendszer alapján adjuk meg. Az eredeti irányok esetén az (5) rendszer harmadik egyenlete az alábbi módon írható: $s \Delta x+x \Delta s=\mu e-x s$.

2. táblázat. Eredmények

\begin{tabular}{|c|c|c|}
\hline Feladat & $\begin{array}{c}\text { Iterációszám } \\
\text { (eredeti) }\end{array}$ & $\begin{array}{c}\text { Iterációszám } \\
\text { (módosított) }\end{array}$ \\
\hline afiro.mps & 20 & 33 \\
\hline sc50a.mps & 36 & 35 \\
\hline sc105.mps & 66 & 44 \\
\hline sc205.mps & 130 & 56 \\
\hline
\end{tabular}

A táblázat alapján azt a következtetést vonhatjuk le, hogy a feladattól függően, vannak olyan esetek, amikor a módosított algoritmus jobb eredményeket szolgáltat, mint az eredeti.

\section{Következtetések}

Ebben a cikkben egy új lineáris optimalizálásra vonatkozó belsőpontos algoritmust vezettünk be. A centralizálási egyenleten egy új ekvivalens átalakítást végeztünk el, ezáltal új keresési irányokat határoztunk meg. Az algoritmust egy $\mathrm{C}++$ programozási nyelvben írt alkalmazással vizsgáltuk különböző MPS formátumban megadott feladatokra. Az eredmények alapján arra a következtetésre jutottunk, hogy az új algoritmus bizonyos esetekben hatékonyabban müködik, mint az eredeti keresési irányokra épülő módszer. Az iterációk számára vonatkozó alaposabb elemzés a feladat jellegétől, a bemeneti paraméterektől, illetve a kezdeti pontoktól függően, egy jövőbeli kutatás tárgyát képezheti.

\section{Köszönetnyilvánítás}

A cikk a Collegium Talentum és az Erdélyi Múzeum-Egyesület támogatásával készült. A szerzők köszönetüket fejezik ki a kutatási munkához nyújtott támogatásért.

\section{Szakirodalmi hivatkozások}

[1] Dantzig, G.B.: Linear Programming and Extension, Princeton University Press, Princeton, 1963.

[2] Darvay, Zs.: New interior point algorithms in linear programming, Advanced Modeling and Optimization, 2003, 5(1):51-92.

[3] Karmarkar, N.K.: A new polynomialtime algorithm for linear programming, Combinatorica, 1984, 4:373-395.

[4] Klee V., Minty G.: How Good is the Simplex Algorithm?, In O. Sisha (ed.), Inequalities, III, Academic Press, New York, 1972.

[5] Roos, C., Terlaky, T., Vial, J.-P.: Interior Point Methods for Linear Optimization, Springer, 2006.

[6] Sonnevend, Gy.: An "analytic center" for polyhedrons and new classes of global algorithms for linear (smooth, convex) programming. In A. Prékopa and J. Szelezsán and B. Strazicky (eds.), System Modeling and Optimization: Proceedings of the 12th IFIPConference held in Budapest, Lecture Notes in Control and Information Sciences, Springer Verlag, Berlin, 1986, 84:866-876.

[7] Wright, S.J.: Primal-Dual Interior-Point Methods, SIAM, 1997.

[8] Ye, Y.: Interior Point Algorithms, Theory and Analysis, John Wiley \& Sons, 1997.

[9] http://www.netlib.org/lp/data/, Netlib test collection. 